\title{
新しい医療機器評価
}

\author{
池田浩治
}

\section{New Medical Device Evaluation}

\author{
Koji Ikeda \\ Clinical Research, Innovation and Education Center, Tohoku University Hospital; \\ 1-1 Seiryo-machi, Aoba-ku, Sendai 980-8574, Japan.
}

(Received August 4, 2015)

\begin{abstract}
In this presentation, as a member of the Harmonization by Doing (HBD) project, I discuss the significance of regulatory science in global medical device development and our experience in the international collaboration process for medical devices. In Japan, most innovative medical therapeutic devices were previously developed and exported by foreign-based companies. Due to this device lag, Japanese had minimal opportunities for receiving treatment with innovative medical devices. To address this issue, the Japanese government has actively accepted foreign clinical trial results and promoted global clinical trials in projects such as HBD. HBD is a project with stakeholders from academia, regulatory authorities, and industry in the US and Japan to promote global clinical trials and reduce device lags. When the project started, medical device clinical trials were not actively conducted in Japan at not just hospitals but also at medical device companies. We started to identify issues under the concept of HBD. After 10 years, we have now become key members in global clinical trials and able to obtain approvals without delay. Recently, HBD has started promoting international convergence. Physicians and regulatory authorities play central roles in compiling guidelines for the clinical evaluation of medical device development, which will be a more active field in the near future. The guidelines compiled will be confirmed with members of academia and regulatory authorities in the United Sates.
\end{abstract}

Key words_ _ device lag; Harmonization by Doing; medical device; regulatory science

\section{1. 医療機器の承認審査体制}

医療機器の規制がどのように行われているかご存 知であろうか. メス，ピンセットのような外科手術 に用いる道具からステント，ペースメーカーのよう な埋植医療機器に至るまで, 医療機器は千差万別で ある. メス，ピンセットのような医療機器から人工 心臓や除細動器まで同じ基準で審査をすると，ある 種の医療機器については規制が厳しくなってしまう など，適切な規制が取り難くなることは容易に想定 される。したがって，医療機器はリスクに合わせ て，審査の制度，審査機関を変える規制体系がとら れている。例えば，厚生労働大臣の承認が必要なも のは，不具合が発生した際に人体へのリスクが比較

東北大学病院臨床研究推進センター（T980-8574 仙台 市青葉区星陵町 1-1)

e-mail: koji-ike3@hosp.tohoku.ac.jp

本総説は, 日本薬学会第 135 年会シンポジウム S38 で 発表した内容を中心に記述したものである.
的高いと想定されるクラス III 以上の医療機器に限ら れている.

一方，海外においては，品質，安全性に関する自 己宣言を中心とした CE マーキングを柱とした第三 者認証制度を導入している欧州連合と，すべて Food and Drug Administration（FDA）で規制を行 う米国の 2 つがよく知られているが，いずれの規制 においてもリスク分類に合わせた規制体系を構築し ている.

わが国では，厚生労働大臣の承認が必要な医療機 器については, 独立行政法人医薬品医療機器総合機 構 (Pharmaceuticals and Medical Devices Agency; PMDA）で承認審査が行われている。医療機器の 承認審査体制は，PMDA 発足時には 30 人にも満た ない人数であったが，平成 21 年に開始された“医 療機器審査迅速化アクションプログラム”1)の中で, 医療機器審査に従事する審査員は 104 人に増員が図 られた。このプログラムでは，新医療機器の承認ま 
での期間を 19 力月短縮することを目標として掲 げ，相談の質・量の向上による開発期間の短縮，審 査体制の拡充強化による承認審査期間の短縮が図ら れている，承認審査期間の短縮については確実に成 果を挙げ, 平成 25 年度の PMDA の新医療機器の 総審査期間（優先審査品目 9.0 力月，通常審査品目 6.3 力月 $)^{2}$ は目標值（総審査期間の中央值として優 先審査品目 10 力月，通常審査品目 14 力月）を満た している.

\section{2. 医療機器と医薬品の違い}

医療機器と医薬品の違いを考えてみたことがある だろうか。薬事法改正により，法令の表題に挙がつ てきたとはいえ，比較して考えた人はそれほど多く ないのではないだろうか. 医薬品, 医療機器等の品 質，有効性及び安全性の確保等に関する法律（以 下，医薬品医療機器等法）の関連条文をみると，法 令の文言的には相補的な関係であることに気づくだ ろう。医薬品と目的は全く同じであって，機械器具 であれば医療機器，そうでなければ医薬品という関 係性である。このため，基本的な考え方，例えばリ スクベネフィットによる承認の可否の判断や, 臨床 試験のプライマリエンドポイントの考え方は双方で 共通の考え方を有している.

形状，使用方法という面ではどうであろうか．粉 末，液体のように比較的シンプルな形状である医薬 品に比べ，医療機器は電気を用いた医用電気機器か ら，人工心臓弁のようにカーボン製のハイテク材料 でできているもの，創傷被覆材やコンタクトレンズ のように材質・形状自体に機能を持たせているもの と様々である.

このように, 医療機器は薬事承認申請書において 規定する内容に限っても，バリエーションが豊富と なっており，簡単にまとめられるものではない，期 待される効能・効果にしても長期的に評価が必要な ものから，術中の負担軽減にのみ使われるものな ぞ，位置づけは様々であり，治療リスクの大きさ， 治療手技の困難さ，材料特性など，製品に求められ る有効性，安全性を左右する因子は多岐にわたるこ とが理解できよう。

次に開発段階における医薬品との違いについて考 えてみよう。これまで述べてきたように医療機器は 製品の多様性が極めて大きいため, 製品群毎に開発 の考え方を取りまとめることはできても，すべての
製品群において実施することは不可能に近い。一 方，広い製品群全体を一般化して考え方を取りまと めると，概念程度しかまとめられないということに 陥る。このような背景があるため，医療機器開発に おいてはガイドライン等に頼るのではなく, 開発者 が逐一考えて論旨を構築していくことが求められ る. 医薬品ではガイドライン等が整備されているた め, ガイドラインに当てはめて考えがちであるが, 医療機器では何かに当てはめるのではなく, 開発全 体を俯瞰して総論的に考え，全体像を構築して開発 を進めることが重要である.

\section{3. 医療機器開発の国際化}

医療機器の輸出入比率の推移3)を見てみよう。こ こ数年国内出荷額は上昇しているが，輸入への依存 度（売上高の $44 \%$ ）も高くなってきており，平成 23 年では約 5700 億円程度の輸入超過が認められて いる. 診断系医療機器に比べ治療系医療機器の伸び は大きく, 平成 19 年度以降の 5 年間で 1.3 倍に拡 大し，国内市場の $53 \%$ を占めている. ${ }^{3)}$ また，治療 系医療機器の輸入額と輸出額の比は 4 倍を超えてお り, 治療系医療機器は海外企業頼みになっていると いって過言ではない.

日本から新しい治療機器がうまれない中, 海外か らは次々と新しい医療機器が発表されており，国内 の臨床医も新製品の情報を耳にするうちに，新しい 医療機器が国内で使えない，いわゆるデバイスラグ の問題に直面することとなる，デバイスラグは平成 14 年度ごろには表面化し始め, ${ }^{4)}$ 特に薬物溶出型ス テント, 大動脈ステントグラフト等の導入遅れ等か ら，問題視されていった。

\section{Harmonization By Doing $(\mathrm{HBD})^{5)}$ のインパク} 卜

日米の医療機器の開発の促進と規制のハーモナイ ゼーションを図ることを目的として，産官学の協力

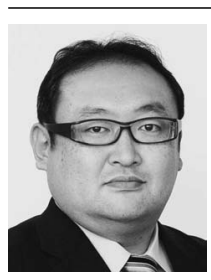

池田浩治
1995 年岐阜薬科大学卒業. 博士課程修 了後, 医薬品医療機器審査センター審 査官として赴任。組織改編により独医 薬品医療機器総合機構に異動し, 医療 機器審査担当として 2012 年まで勤務. 退職後, 東北大学病院臨床研究推進セ ンターにて, 医薬品・医療機器開発の 支援業務に従事。専門はレギュラト リーサイエンスとトランスレーショナ ルリサーチ. 
で開始された活動が HBD である. ${ }^{6}$ 平成 15 年 12 月に最初の Think Tank Meeting が開かれ，平成 18 年 7 月からは，厚生労働省及び FDA の連携の下, 正式に 4 つの WG による活動が行われている。 こ の活動の特徴は, 単にガイドラインを策定するので はなく，実際に具体的な事例を動かしつつ整合化を 進めることであり，その進め方が，“Harmonization By Doing”と称される由縁である。

HBD では，革新的医療機器の日米での同時開発 を促進するため，(1)単一治験プロトコルの作成，(2) 両国当局への同時並行の治験相談とその情報交換, (3)日米共同治験の実施, (4)同時並行した承認申請 ・ 審査とその情報交換を実施することを具体的な課題 に掲げ，日米間での規制や環境の違い及び実施上の 問題点を明らかにし，それらを解決する方策を案出 し，さらにその有効性を検証すべく検討を進めて いった。

HBD のワーキンググループが最初にチャレンジ した課題が， 2 種類の薬物溶出型ステント (Xience $\mathrm{V}$ ：アボットバスキュラー株式会社，Endeavor：日 本メドトロニック株式会社）であった．薬剤溶出型 ステントは既に日本での承認前例があったが，いず れも米国に遅れて国内治験が行われたことなどが原 因で，米国での承認時期からは遅れて承認を得てい る品目であった． 2 品目について HBD の中で取り 扱われ，米国治験では比較試験であったところが， 国内治験では単腕試験であったことを除き，ほぼ同 一のプロトコルで治験が実施された。開始時期のず れはあったが，同時期に PMDA, FDA の規制当局 との相談を踏まえてプロトコルを完成させ，施設へ の調整，規制当局への提出文書の作成を経て，米国 との共同治験を遂行することができた。この経験は お互いの規制当局，参加企業だけでなく，医療現場 に自信と希望を与えた画期的な出来事であった.

それを証拠に，このあとは完全に同一の国際共同 治験の遂行も経験し，2009 年に実施された Zilver PTX 薬剤溶出型ステント（Cook Japan 株式会社） の治験では，世界の多くの施設を差し置いて，日本 の施設が実施症例数の上位に並ぶなど，「時間がか かる」，「品質が悪い」と揶揄された懸念を払拭する ことに成功した．このように，HBD の主旨の通り， “Doing”により実践と並行して経験を積み, 改善 することで，当該分野の治験環境は劇的に改善した
ことは，HBD の大きな成果であったが，真の成果 はそれだけには留まらなかった。

\section{5. 日米同時開発の時代へ}

Zilver PTX 薬剤溶出型ステントにおいては, FDA-厚生労働省 (Ministry of Health, Labour and Welfare; MHLW)/PMDA Collaborative Scheme ${ }^{7)}$ という新しい試夕が行われた。これは，これまでの HBD での検討結果を踏まえ，開発段階で非公開情 報を含む個別品目について, FDA と厚生労働省・ PMDA が両国での治験相談や承認審査に当たつて 情報交換を行うことに合意した実質的な同時審査ス キームである，この取組みは，日本，米国の双方の 企業から候補品目が選定されて実施され，いずれの 品目もデバイスラグの解消に役立っている. 中でも Zilver PTX 薬剤溶出型ステントは, 開発国の米国 よりも早く国内承認を達成するなど，大きな成果を 挙げることができたことは記憶に新しい.

医療機器開発の国際調和は，国際共同治験のス テージを超え，日米規制当局への同時申請のレベル に進化することができた。これは，規制当局間の意 見交換が活発化し，考え方の共有が図られた結果に ほかならないが，その根底には信頼関係の構築が大 きな役割を担っていると思われる。この信頼関係 は, 新しい領域の医療機器開発において力を発揮し 始めている．例えば，重症下肢虚血の領域では日米 の産官学が集まり，治験プロトコルの骨子に関する 考え方が議論され，日本では評価指標 ${ }^{8}$ が作成され ている.

医療機器の領域において治験や評価が難しい事例 があるが，それは日米共通であることを踏まえ，新 しく難しい品目であればあるほど，国際的な議論を 早期に展開し，海外デー夕を上手に利用して日米双 方の承認を得ていくことが重要となってくる．いま や新しい医療機器開発はグローバル化の時代になつ てきていると言っても過言ではない.

利益相反＼cjkstart開示すべき利益相反はない.

\section{REFERENCES}

1) Ministry of Health, Labour and Welfare. "Iryoukiki no shinsajinsokuka action program no sakutei ni tsuite.”: 〈http://www. mhlw.go.jp/topics/2009/01/tp0105-2.html , 
cited 30 June, 2015.

2) "Dokuritsu gyouseihoujin iyakuhin iryoukiki sougoukikou no chukimokuhyoukikan no gyoumujisseki no saishuhyoukakekka.": 〈http: // www.pmda.go.jp / files / 000198091. pdf $\rangle$, Pharmaceuticals and Medical Devices Agency Web, cited 25 September, 2015.

3) Ministry of Health, Labour, and Welfare. “Iryoukiki Sangyo Vision 2013."” 〈http:// www.mhlw.go.jp / seisakunitsuite / bunya / kenkou_iryou / iryou / shinkou / dl / vision _ 2013b.pdf $\rangle$, cited 30 June, 2015.

4) Ministry of Health, Labour and Welfare, “Iryoukiki sangyo vision 2013.': 〈http:// www.mhlw.go.jp / seisakunitsuite / bunya / kenkou_iryou / iryou / shinkou / dl / vision _ 2013c.pdf $\rangle$, cited 25 September, 2015.

5) Pharmaceutical and Medical Devices Agency. “HBD (Harmonization By Doing).": 〈https: / / www.pmda.go.jp / int-activities / int-harmony/hbd/0015.html $\rangle$, cited 30 June, 2015.

6) Iwamoto S., Ho M., Suzuki Y., Regulatory
Science of Medical Products, 5, 227-234 (2015).

7) The Director of Office of Medical Devices Evaluation, Evaluation and Licensing Division, Pharmaceutical and Food Safety Bureau, Pharmaceutical and Medical Safety Bureau, Ministry of Health, Labour and Welfare. "Beikokushokuhiniyakuhinchou tono iryoukiki no taimenjogen oyobi shouninshinsa nikakaru jouhoukoukan no shikou nitsuite.": 〈http: // www.pmda.go.jp / files / 000160471. pdf $\rangle$, Pharmaceuticals and Medical Devices Agency Web, cited 30 June, 2015.

8) The Director of Office of Medical Devices Evaluation, Evaluation and Licensing Division, Pharmaceutical and Food Safety Bureau, Pharmaceutical and Medical Safety Bureau, Ministry of Health, Labour and Welfare. "Jisedaiiryoukiki hyoukashihyou no kouhyo nitsuite.": 〈http://www.pmda.go.jp / files / 000161654.pdf $\rangle$, Pharmaceuticals and Medical Devices Agency Web, cited 30 June, 2015. 